UDC $551.4+477.86$

Oleh M. Adamenko ${ }^{1}$, D. S., Professor of Ecology Institute of Natural Sciences and Tourism, Department of Ecology

ORCID ID 0000-0003-0821-3011 e-mail: katolrad22@gmail.com

Macej Kotarba², Professor, dr. hab. inz., Faculty of geology, geophysics and environmental protection

Kateryna O. Radlowska ${ }^{1}, \mathrm{PhD}$, Associate Professor of Ecology

ORCID ID 0000-0003-2640-4735 e-mail: katolrad22@gmail.com

Mykola I. Mosiuk ${ }^{1}, \mathrm{PhD}$, Associate Professor

ORCID ID 0000-0002-9828-7331 e-mail: mosiuk@ukr.net

Valery G. Omelchenko ${ }^{1}, \mathrm{PhD}$, Director of the Institute of Natural Sciences and Tourism

Slawomir Bebenek ${ }^{2}$, dr. inz., Faculty of geology, geophysics and environmental protection e-mail: sbebenek@agh.edu.pl

Volodymyr R. Khomyn ${ }^{1}$, D. S., Professor, Head of the Department of Engineering Geology and Hydrogeology

Jacek Matyszkiewicz ${ }^{2}$, Professor, dr. hab. inz., Faculty of geology, geophysics and environmental protection

e-mail: jamat@agh.edu.pl

${ }^{1}$ Ivano-Frankivsk National Technical University of Oil and Gas, Ivano-Frankivsk, Ukraine

${ }^{2}$ AGH University of science and technology, Krakow, Poland

\title{
STARUNYA: FROM GEOLOGICAL MONUMENT TO NATURE UNESCO GEOPARK
}

Summary. One of the natural wonders of Prykarpatya is the village Starunia - with embalmed in ozokerite and well-preserved carcasses of mammoths and hairy rhinos and an active mud volcano, will undoubtedly delight us with new exploratory discoveries in the field of geology, paleontology and archeology. It is possible that here, together with large fossil mammals of the Ice Age, the remains of hunters on them - our ancestors Cro-Magnons - could be preserved. This discovery would have, without the slightest exaggeration, an international dimension. Therefore, it is necessary to continue the comprehensive study of Starunia, to promote it among environmentalists, scientists, students and schoolchildren. All this develops a love for native nature, encourages the preservation of its unique objects and historical and cultural heritage.

The preparation of "Starunia" for the UNESCO World Geoparks Network by specialists of the Ivano-Frankivsk National Technical University of Oil and Gas (IFNTUNG) in accordance with UNESCO requirements is highlighted by UNESCO Geoparks Program.

According to these requirements to give the geological monument of nature "Starunia" the status of "geopark" it is necessary to study and give a standard description of all components of the environment: geological environment and endogeodynamic processes, relief (geomorphosphere) and dangerous

O.M. Adamenko, M. Kotarba, K.O. Radlowska, M.I. Mosiuk, V.G. Omelchenko,

S. Bebenek, V.R. Khomyn, J. Matyszkiewicz, 2021 
exogeodynamic processes, hydro- and atmosphere, soil and plants cover, social environment, technosphere and their anthropogenic changes; assess the current environmental situation and develop environmental protection measures. This is not yet the case.

In order to further study "Starunia" in IFNTUNG developed Regional Comprehensive Program for 2022-2023 "Starunia: from a natural monument to the geopark of the Ice Age", which was transferred to the Ivano-Frankivsk Regional State Administration and the Regional Council.

Thus, the world-famous geological natural monument of national importance "Starunia" deserves a separate national program and shorter deadlines for its implementation, which would allow including "Starunia" in the world network of UNESCO geoparks.

Keywords: Program; geological monument; geopark; endogeodynamic processes; fauna

DOI: https://doi.org/10.32347/2411-4049.2021.3.44-50

\section{From the history of research}

The first finds of mummified carcasses of a hairy rhinoceros, mammoth remains of a horse, roe deer and other animals of the Pleistocene so-called mammoth fauna were made at a depth of $12.6 \mathrm{~m}$ when digging a mine (mine) for ozokerite production near the village. The elders of the Bohorodchany district of the Ivano-Frankivsk region in 1907. Scientists from Krakow and Lviv appreciated these unique discoveries and published a number of articles and a monograph in 1914 [10].

In 1929 expedition of the Academy of Skills from Krakow while digging a mine at a depth of $17 \mathrm{~m}$ found the remains of 3 more hairy rhinos. Numerous bones of small vertebrates (rodents), shell remains, numerous species of insects, beetles, parasitic worms, butterflies, spiders, snails, vascular plants, seeds and branches of dwarf birch, alder and other tundra flora were also collected. Polish scientists organized a comprehensive study of fauna and flora, some of their results were published in articles, but World War II suspended this process [11].

In the period between the First and Second World Wars, as well as in the postwar years 1945-1969, ozokerite deposits (Starunske and Dzvinyachske) were explored in Starunia and neighbouring areas, which continued to be developed. Intensive oil exploration was also carried out, but its deposits, including in the dome of the Starunia fold, were used for industrial exploitation $[4,6,7,12]$.

In March 1977 after the earthquake, the first and mud volcano appeared in the ozokerite deposit, which added a new "sound" to the Starunia paleontological site. Professors of the Ivano-Frankivsk Institute of Oil and Gas, doctors of geological and mineralogical sciences Nadiya Bilous and Veniamin Klyarovsky studied the manifestations of mud volcanism in Starunia during 1977-1988. They "achieved" the registration of this area of 60 hectares as a geological natural monument of national importance [5].

During the same period, geologists O.M. Adamenko, O.R. Stelmakh, G.D. Stelmakhovych, N.M. Shevchuk, V.V. Kolenchenko and other employees of the Department of General Geology of IFNTUNG were involved in the study of Starunia [1-3]. They were joined by paleontologists of the Natural History Museum of the Academy of Sciences of Ukraine (Lviv) D.M. Dragant and others.

In the 70-80 years of the XX century archaeologist of the Institute of Ukrainian Studies named after I. Krepyakevych of the Academy of Sciences of Ukraine 
L.G. Matskevy together with archaeologists of the Ivano-Frankivsk Pedagogical Institute named after V. Stefanyk B.A. Vasylenko and I.T. Kochkin conducted excavations around Starunia. Several dozen sites of ancient man of the Late Paleolithic, Mesolithic and Neolithic epochs have been discovered [8-13].

It is worth mentioning that back in 1914 Professor M. Lomnitsky wrote about a hairy rhinoceros, and a fragment of a wooden spear with a pointed end was found nearby: The original hunters of these animals were the Cro-Magnons, who caught and drove their prey into the ozokerite trap of the salt lake.

In 1988-1989, the Ivano-Frankivsk Institute of Oil and Gas for the first time officially organized state budget research at the expense of funding from the Ministry of Education and Science of Ukraine on the Starunia mud volcano under the leadership of O.M. Adamenko. The direct executors of the topic were O.R. Stelmakh, L.M. Mykhalska, I.R. Mykhailyuk and other employees of the Department of General Geology (since 1989 - the theoretical foundations of geology).

The approaching date of the 100th anniversary (2007) of paleontological finds in Starunia led to the intensification of interdisciplinary research of this geological monument [2]. The monograph of the Krakow professor Stefan Alexandrovich "Starunia" was published [9], and the President of the Polish Society "Geosphere" the professor of the Krakow Mining and Metallurgical Academy named after S. Stashitsa Maciej Kotarba suggested to Professor Oleg Adamenko, who from 1974 to the present continued to study Starunia as an endogeodynamic landfill, to start joint research of all processes at this landfill.

In 2004, two Ukrainian-Polish expeditions were organized - the first in May and the second in October at the expense of budget funding from the Ministry of Education and Science of Poland.

The results of research of both expeditions were published in 2005 in the book "Polish and Ukrainian geological studies (2004-2005) at Starunia - the area of Discoveries of Wolly Rhinoceroses" edited by prof. M. Kotarba [12, 14].

In 2005 a scientific conference was held in Krakow, and in 2008 in IvanoFrankivsk. They were dedicated to the 100th anniversary of paleontological finds with excursions to Starunia, with a broad discussion of the scientific results of the 2004-2005 expeditions and coverage in several collections of materials and media.

The next stage of Starunia's interdisciplinary research took place in 2006-2009, when under the leadership of Professors M. Kotarba and O. Adamenko it was possible to organize drilling of several dozen wells with 100 percent core yield for detailed study of Quaternary sediments. Geological-geomorphological, geochemical, geophysical researches also continued [2].

The results of these studies are published in the scientific collection "Interdisciplinary studies (2006-2009) at Starunia (Carpathian region, Ukraine) the area of discoveries of Wolly Rhinoceroses" [12]. The main achievements are set out in 17 articles - [12].

An important result was the discovery of the most favourable area, where the remains of giant mammals and even Cro-Magnons of the Pleistocene could not be found at depth.

All the numerous interdisciplinary findings of Polish and Ukrainian scientists confirm the uniqueness of Starunia on a global scale; require the preservation and further study of paleontological finds and the only active mud volcano in the Carpathians. Such findings can be made only by organizing the Starunia Scientific Geodynamic Landfill Ecological and Tourist Center Geopark - UNESCO [15]. 


\section{Presenting main material}

To do this, you must perform the following tasks:

1. Mark the boundaries of the geological natural monument "Starunia" and Starun Scientific Geodynamic Landfill, where a geopark will be created under the auspices of UNESCO [15];

2. Creation and maintenance of the website "Starunia - on-line" [3, 4];

3. Installation in the village. Starunia of Bohorodchany district and IvanoFrankivsk region, along the highways of Ivano-Frankivsk - Lviv, Ternopil, Uzhhorod, information stands, pylons, light boxes, models, models that will promote the tourist potential of the region $[4,12]$;

4. Generalization of existing materials for assessing the ecological status of environmental components on the geological monument of nature "Starunia" geological environment, geodetic and geochemical fields, geomorphosphere, neotectonics and paleography $[4,12]$;

5. Field expeditionary researches on the territory of the geological natural monument "Starunia" of ecological condition of soil and vegetation covers, surface and spring waters, atmospheric air, and snowfalls with sampling;

6. Laboratory and analytical determination of the content of pollutants - heavy metals, cadmium, lead, copper, zinc and petroleum products, radioactive substances and excess mineral fertilizers and pesticides;

7. Ecological-techno-geochemical mapping and ecological zoning to assess the ecological condition and ecological safety of the monument "Starunia";

8. Substantiation of the international bus route from Poland to Ukraine - Krakow Novoyavorivsk - Mariampol - Halych - Starunya - Bukovel [4];

9. Organization of children's, pupils 'and students' ecological schools for ecological education for kindergarten to university [4];

10. Development of feasibility study - feasibility study and technical specifications - terms of reference for the creation of a geopark of the Ice Age [15].

Discussion of the obtained results. In order to prove the suitability of additional research of the geological monument "Starunia" the possibility of raising its status to the UNESCO Geopark, it is necessary to compare the relevant requirements set out in the UNESCO document [15].

\section{Conclusions}

Expected results of the planned activities:

1. Protection of the world-famous geological natural monument "Starunia" paleontological burial place of the ancient fauna of rhinos and mammoths and the only active mud volcano in the Carpathians;

2. Feasibility study (feasibility study) and terms of reference (TOR) to raise the category of nature reserves "Starunia" to the level of "geopark" of the Ice Age in accordance with the requirements of UNESCO;

3. Development of international tourism in the Carpathians and recreational attractiveness of Starunia, which will contribute to the socio-economic development of local communities;

4. Educational and upbringing activities on the basis of the geological monument of nature and the future geopark; 
5. Ensuring scientific research of the natural heritage of Prykarpatya and the geological monument of nature "Starunia" as one of the markers;

6. Global climate change;

7. Improving conditions for recreation and treatment of residents of the region.

\section{REFERENCES}

1. Adamenko, O.M. (2007). Starunia - the future Park of the Ice Age I. In: Our future home EcoEurope. The novel of life, science and love in 4 volumes. (Vol. IV, pp. 105-183). IvanoFrankivsk: Symphony forte.

2. Adamenko, O.M., Adamenko, Ya.O., Ambrozyak, M.V., Vekeryk, V.I., Gladun, J.D., Zorin, D.O. et al. (2008). Starunia - a unique geological monument of nature with fossil fauna of hairy rhinos and mammoths and manifestations of mud volcanism. In: Natural and Historical Heritage of Starunia. (pp. 9-12). Starunia - Lviv - Ivano-Frankivsk - Krakow: Akapit.

3. Adamenko, O.M., Mishchenko, L.V., Mosyuk, I.V., Stelmakh, O.R., Zorin, D.O., Prikhodko, M.M., \& Radlovska, K.O. (2011). Starunia's geodynamic landfill - Park of the Ice Age I. EB and 3R-2011, 1 (3), 75-76.

4. Alexandrovich, Sh.V., Gladun, Ya.D., \& Kulish, V.V. (2008). Starunia and the study of the Quaternary period in the tradition and initiatives of the Polish Academy of Skills I. IvanoFrankivsk.

5. Belous, N.X., \& Klyarovsky, V.M. (1987). Miracle-Starunia. In: 11 Geological monuments of Ukraine (pp. 48-49). Kyiv: Naukova dumka.

6. Stelmakh, O.R., Kashchyshyn, O.K., Mosyuk, I.V., \& Mishchenko, A.V. (2014). History of the study and collection of ores and artifacts of the geodynamic landfill "Starunia". EB and $C L, 1(9), 49-52$.

7. Adamenko, O.M., Krizhanivskiy, E.I., Vekeryk, V.I., Stelmach, O.P., Mischenko, L.V., Zorina, N.O., Zorin, D.O. \& Ambrozyak, M.V. (2005b). A concept of an international "IceAge Geopark" as an ecological-tourist center in Starunia former ozokerite mine, foreCarpathian region, Ukraine. In: Kotarba M. J. (ed.), Polish and Ukrainian geological studies (2004-2005) at Starunia - the area of discoveries of woolly rhinoceroses (pp. 205-209). Warszawa-Kraków: Polish Geological Institute and Society of Research on Environmental Changes "Geosphere".

8. Adamenko, O.M. (2019). The Upper Pleistocene stratigraphy of the Starunya site as a "bridge" between the stratigraphical frameworks of Western Europe and the plain area of Ukraine. Journal of Geology, Geography and Geoecology, 28(2), 213-220. doi: https://doi.org/10.15421/111922.

9. Alexandrowicz, S.W. (2004). Starunia and the Quaternary research in the tradition and initiatives of the Polish Academy of Arts and Sciences. Studia i materiały do dziejów Polskiej Akademii Umiejętności, 261 pp. (in Polish, English summary).

10. Bayger, J.A., Hoyer, H, Kiernik, E., Kulczyński, W., Łomnicki, M., Łomnicki, J., Mierzejewski, W., Niezabitowski, E., Raciborski, M., Szafer, W. \& Schille, F. (1914). Wykopaliska Staruńskie. Muzeum im. Dzieduszyckichwe Lwowie, 15: 386 pp.

11. Kotarba, M.J. (Ed.). (2005). Polish and Ukrainian geological studies (2004-2005) at Starunia - the area of discoveries of woolly rhinoceroses. Polish Geological Institute and Society of Research on Environmental Changes «Geosphere», Warszawa-Kraków: 218 pp. 12. Kotarba, M.J. (Ed.). (2009). Interdisciplinary studies (2006-2009) at Starunia (Carpathian region, Ukraine) - the area of discoveries of woolly rhinocerouses. Annales Societatis Geologorum Poloniae, 79(3), 217-480.

13. Matskevyj, L.G. (2005). Archaeological sites in the Starunia area, fore-Carpathian region, Ukraine. In Polish and Ukrainian geological studies (2004-2005) at Starunia - the area of discoveries of woolly rhinoceroses (pp. 45-51). 
14. Sokolowski, T., \& Stachowicz-Rybka, R. (2009). Chronostratigraphy and changes of environment of Late Pleistocene and Holocene at Starunia palaeontological site and vicinity (Carpathian region, Ukraine). Annales Societatis Geologorum Poloniae, 79, 315-331.

15. UNESCO Geopark Program - a new initiative to promote a global network of geoparks safeguarding and developing selected areas having significant geological features. (1999). Hundred and fifty-sixty session. United Nations Educational, Scientific and Cultural Organization: Executive Board (pp. 1-4). Paris.

The article was received 28.04.2021 and was accepted after revision 02.07.2021

О.М. Адаменко, М. Котарба, К.О. Радловська, М.І. Мосюк, В.Г. Омельченко, С. Бебенек, В.Р. Хомин, Я. Матишкевич «СТАРУНЯ»: ВІД ПАМ'ЯТКИ ПРИРОДИ ДО ГЕОПАРКУ ЛЬОДОВИКОВОГО ПЕРІОДУ

Анотація. Одним із природних чудес Прикарпаття $\epsilon$ село Старуня - iз забальзамованими в озокериті та добре збереженими тушами мамонтів та волохатих носорогів та діючим грязьовим вулканом, яке, безперечно, порадує нас новими дослідницькими відкриттями в галузі геології, палеонтології та археології. Не виключено, що тут разом з великими викопними ссавцями Льодовикового періоду могли зберегтися рештки мисливців на них - наших предків кроманьйонців. Це відкриття мало би, без найменшого перебільшення, міжнародний вимір.

Підготовка "Старуні" до включення до Всесвітньої мережі геопарків ЮНЕСКО спеціалістами Івано-Франківського національного технічного університету нафти i газу (ІФНТУНГ) регламентується програмою ЮНЕСКО з геопарків.

Відповідно до цих вимог, щоб надати геологічній пам'ятці природи «Старуня» статус «геопарку», необхідно вивчити та дати стандартний опис усіх складових середовища: геологічного середовища та ендогеодинамічних процесів, рельєфу (геоморфосфери), небезпечних екзогеодинамічних процесів, гідро- та атмосфери, грунту та рослинного покриву, соціального середовища, техносфери та іï антропогенних змін; оцінити поточну екологічну ситуацію та розробити заходи з охорони довкілля.

3 метою подальшого вивчення "Старуні" в ІФНТУНГ розроблена Регіональна комплексна програма на 2022-2023 роки «Старуня: від пам’ятки природи до геопарку Льодовикового періоду», яку передано Івано-Франківській ОДА та обласній раді.

Таким чином, всесвітньо відома геологічна пам'ятка природи національного значення "Старуня" заслуговує на окрему національну програму та скорочення термінів її імплементації, що дозволило б включити "Старуню" до світової мережі геопарків ЮНЕСКО.

Ключові слова: програма; геологічна пам'ятка; геопарк; ендогеодинамічні процеси; фауна

Стаття надійшла до редакиії 28.04.2021 і прийнята до друку після рещензування 02.07.2021

\section{Адаменко Олег Максимович}

доктор геолого-мінералогічних наук, професор кафедри екології Івано-Франківського національного технічного університету нафти і газу

Адреса робоча: 76019 Україна, м. Івано-Франківськ, вул. Карпатська, 15

ORCID ID 0000-0003-0821-3011 e-mail: katolrad22@gmail.com

\section{Котарба Мацей}

професор, доктор наук, факультет геології, геофізики та охорони навколишнього середовища

Краківська гірничо-металургійна академія ім. С. Сташіца

Адреса робоча: 30-059 Краків, пров. Міцкевича 30, Польща 


\section{Радловська Катерина Олексіївна}

кандидат технічних наук, доцент кафедри екології Івано-Франківського національного технічного університету нафти і газу

Адреса робоча: 76019 Україна, м. Івано-Франківськ, вул. Карпатська, 15

ORCID ID: https://orcid.org/0000-0003-2640-4735 e-mail: katolrad22@gmail.com

\section{Мосюк Микола Іванович}

кандидат технічних наук, доцент кафедри екології Івано-Франківського національного технічного університету нафти і газу

Адреса робоча: 76019 Україна, м. Івано-Франківськ, вул. Карпатська, 15

ORCID ID 0000-0002-9828-7331 e-mail: mosiuk@ukr.net

\section{Омельченко Валерій Григорович}

кандидат технічних наук, директор Інституту природничих наук та туризму ІваноФранківського національного технічного університету нафти і газу

Адреса робоча: 76019 Україна, м. Івано-Франківськ, вул. Карпатська, 15

\section{Бебенек Славомір}

доктор, факультет геології, геофізики та охорони навколишнього середовища

Краківська гірничо-металургійна академія ім. С. Сташіца

Адреса робоча: 30-059 Краків, пров. Міцкевича 30, Польща

e-mail: sbebenek@agh.edu.pl

\section{Хомин Володимир Романович}

доктор геологічних наук, професор, завідувач кафедри загальної, інженерної геології та гідрогеології Івано-Франківського національного технічного університету нафти i газу

Адреса робоча: 76019 Україна, м. Івано-Франківськ, вул. Карпатська, 15

\section{Матишкевич Яцек}

професор, доктор наук, факультет геології, геофізики та охорони навколишнього середовища

Краківська гірничо-металургійна академія ім. С. Сташіца Адреса робоча: 30-059 Краків, пров. Міцкевича 30, Польща

e-mail: jamat@agh.edu.pl 